\title{
Living in the Theme Park: A Textual Tour of Savannah's Public Squares
}

\author{
Tom Lavazzi \\ Kingsborough Community College, New York, USA
}

\begin{abstract}
About the Paper
In drafting this essay, the author has counter-posed two compositional strategies, one based on conventional rhetorical structures, founded in enlightenment concepts of sequential logic, rationality, and isomorphism-i.e., the standard, academically sanctioned thesis essay form, proceeding in an orderly and hierarchical manner from head (main idea) through body (detailed breakdown and investigation of thesis pointsequivalent to scientific testing or proof of an initial hypothesis/proposal, deploying transitions and focal topics to govern and control the content of each subsequent investigative unit (paragraph). From this perspective, the essay structure is very much the rhetorical double of the city plan it proposes to elucidate. Working against this more panoptically controlled hierarchical structure, is a postmodern turn toward [Internet] wwwbased, non-sequential organization. Hence, certain sections of the essay are potentially arrived at via mock-URLs, suggesting the tentative, self-consciously constructed, unnatural nature of the smoothly flowing logical structure; at any moment, a different link could be selected, interrupting/disrupting/complicating the logical and sequential arrangement. Also along these alinear lines are bolded fragments of text, suggesting an associational pattern of connectivity among images and ideas destabilizing and rendering motile the more static, rationally secured surface of the final product.
\end{abstract}

[Key words: Savannah , Public Squares, City, Park]

"philosophical remarks...crisscross in every direction. the best I could write...no more than..." Wittgenstein, Philosophical Investigations.

"Let us suppose that what the traveler seeks is not another place, another co-ordinate on the same mapped surface, but another to place itself."

Tom Cohen, Ideology and Inscription

"I pray that what happened to Charleston doesn't happen to us." Celia Dunn, Savannah realtor

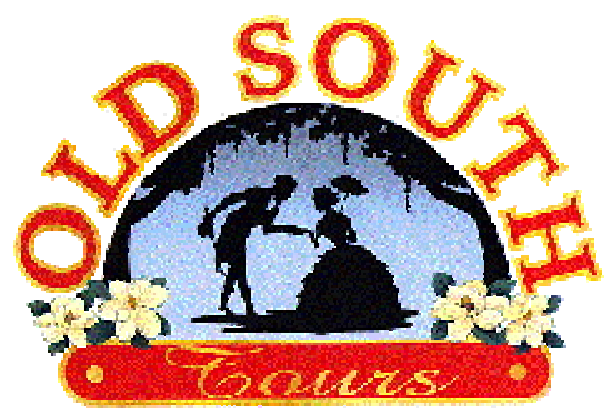

Fig. 1

Rupkatha Journal on Interdisciplinary Studies in Humanities

Volume 2, Number 1, Special Issue, Visual Arts

URL of the Issue: http://rupkatha.com/rupkathav2n1.php 


\section{concept.com ${ }^{1}$}

For many Savannahians, this southern port city is its picturesque downtown of Victorian town houses, with their decorative wrought iron balconies and ornamental woodwork, arranged around quiet landscaped squares; not the sprawling suburbs and condos anchored by megamalls and multilane trafficways to the south. Savannah's squares, bits of public nature (in contrast to the private suburban lawn), are symbolically insulated from the harsher economic realities of urban life. Named for figures significant to the city's early, colonial development, for revolutionary war heroes, for important political/civic leaders, and for historically significant events, some squares sport bronze plaques featuring historical monuments as centerpieces. Since the last of the 24 squares were laid in 1851, their signing of (signifying on) history also closes with the late 19th century; the squares are like encapsulated mementos of the "old south," forcing traffic to pass slowly around them, in pace with the regular horse and buggy tours (a theme park version of "southern living"). Since the Historic District is flanked by public housing developments to the east and west, and low-income neighborhoods immediately to the south, the self-consciously historical presence of these thematic packets (restored 19th-century homes clustered around dowager squares) is a necessary imaginative buoy to a community somewhat insecure about its own historical position and social-economic stability (Savannahians are willing to pay well over $\$ 35,000$ a year per urban dame to maintain appearances); the squares function as an ideological framework bracketing "history" in and socio-economic realities out, evoking pictographic maps that color in the "unpicturesque."

These specular social-historical fantasies are intriguingly elaborated and/or played upon through various textualizations of the city from its founding to the present, including graphic representations, pop histories, guide books, and tourist brochures.

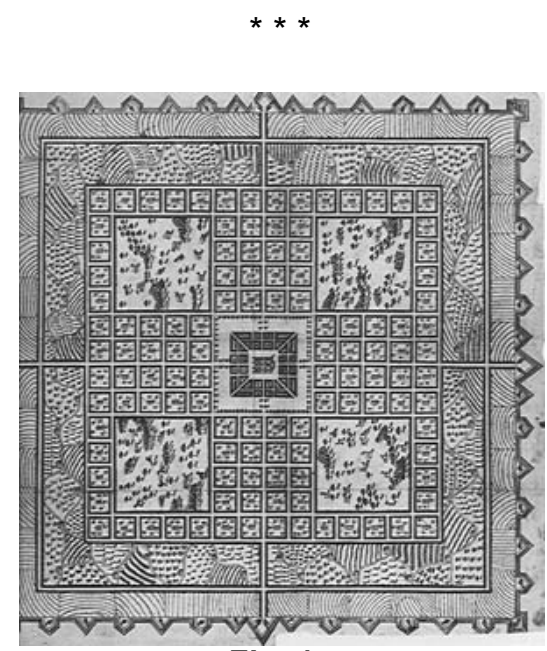

Fig. 1a

\section{ourcoast.com/cityguides /savannahcityguide/visiting/history1....}

"History of Savannah

Are you... Visiting? Wondering or Moving?" 
[proposed] by Edward Oglethorpe in 1733...

The city, the city's history, as commodity fetish...

Mark.

ideology.com/plan/comspec

The city planner as graphic designer. Savannah's founder, General James Edward Oglethorpe, had a vision as ideo-aesthetic as it was pragmatic, guided by a mathematics of morality and the sense of the New World as a stage on which to rehearse concepts of social control. The modular system he developed in 1733 was based on the English model of the ward. Oglethorpe's wards consisted of 12 tracks of land centered around a square; on the north and south, the tracts were divided into four groups of 10 lots each ("tythings"); the east and west tracts were "trust" lots, reserved for public buildings. The squares themselves were "free" spaces that could be traversed in any direction, contrasting with the regularity and uniformity of the deployment of public and private space around them. They "opened" the grid, aesthetically and ontologically, suggesting a harmony, a communication, between the human and natural, but also served practically as meeting places, sites of public events, and a places to retreat to in case of enemy attack ${ }^{2}$.

However, the squares and the ward arrangement were as much about containment and control as about cohabitation of civilization with its (natural) "other." Geometrically, the square--defined in practice more by the arrangement of buildings surrounding it then by the shape of the plot itself, with its rounded edges--is a figure of order and control, which, buttressed by the uniform appearance of the structures enclosing it, should impart a sense of orderliness to activities within it; Oglethorpe's vision was one of purity and order, a (proto)enlightenment fantasy of clockwork precision, efficient function, modular grace, and taxonomic structure. One of the few planned cities (along with Washington and Philadelphia) in 18th-century America, only like Philadelphia (founded in 1683) was Savannah pre-fabricated, on paper (Toledano, 61)--an 18th-century Levittown into which the populace could be inserted. The salutary effects of place, of a planned social-spatial order, of a design that could accommodate and coordinate human life and activity, nature, and architecture required, to put the ergonomic model to test, a social "other" as well-a citizenry that had "failed" under the English system: many of the original settlers were debtors hose release Oglethorpe had secured from London's prisons. The reformist impulse underlying the Savannah plan inspired a uniformity that verged on rigidity: each tything block was divided by a lane, creating eight rectangular territories governing each square, I-Ching-like--four to the north and four to the south; tything lots measured 60' $X 90$,' containing identically constructed and situated $16^{\prime} \times 24^{\prime} X 8^{\prime}$ frame cottages with gardens to one side. The architectural regularity of this proto "planned community" supported a systematic social structure. Each lot owner, as a "tythingman," served double duty as property owner and military unit [one of Oglethorpe's sources for the ward organization was Pietro Cataneo's 1567 etchings (fig. 1a) of the ancient Roman camp system ${ }^{3}$; moreover, one of the tythingmen served as guard for the tything he dwelled in (a rotating function), and each tythe had a constable, so that at any one time the number of internal security figures doubled, plus one, the number of 
sides of the open square, and each resident was, by turns, both populace and police, a brilliant scheme that kept the colony on guard for attacks from without, assured security within, and built a habit of self-surveillance into each citizen. The squares, as originally designed--unlandscaped, open spaces (Morrison, 7), bare stages each citizen had to cross as he/she went about his/her daily business--helped to keep the populace on (in) view (note the placement of human figures in A View of Savannah, below, fig. 2). Savannah originated, then, as a design, in the abstract, as a limning of ideology--a set of socio-cultural instructions, "squares included,' so to speak. ${ }^{4}$

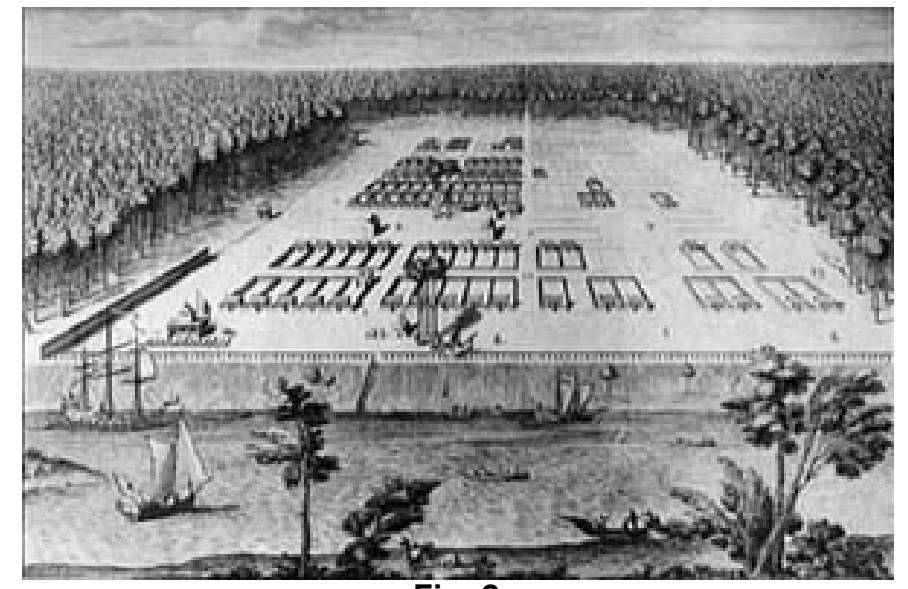

Fig. 2

IGordon.htm

The rhetoric of Peter Gordon's engraving/pictographic map of the founding settlement, "A View of Savannah as It Stood the 29th March 1734" (1734; see fig. 2), is illuminating in this respect, and is perhaps more intriguing then the plan itself. The illustration suggests a fascination with boxing, (sub)division, and taxonomy. The marked (numbered) sites highlight key features of the small community's social-political organization, each with a particular space assigned to it, usually the "trust" lots to the east and west of the square. Each of the identical residential cottages is situated at the head of a fenced-in subdivision of the tything blocks to the north and south of the square. Again, the emphasis of the whole is openness and order, seeing but also being seen. The squares themselves function as clearings, open spaces in the design. Where there are not yet buildings or fences, lots are incised with mathematic precision, creating an interplay of plane geometric figures that can only exist on the paper of the illustration/map itself, like the numbers on key structures. The map hovers somewhere between conceptual drawing--"plan"-- and representation, between perceived and invented "reality." Human presence--a few anonymously etched figures scattered about--is trivial compared to the overall design, a schematic layout of lots and structures. Significantly, one square (St. James, later Telfair; right background) exists almost completely as concept, except for a single structure in its northeastern-most tything lot. Clearly, the map precedes the territory; the beauty and balance of the design informs the order and stability of components. The play of empty, subdivided rectangles around the central square sets the rhythm of the plan; a sense of harmony and security is effected by the mathematics of the layout itself, which 
functions more as a template of consciousness than a reproduction of a site. Also note the aerial point of view (not unlike contemporary tour maps). The viewer is removed from the scene, disembodied, hovering somewhere above it in an abstract space of reason, mesmerized by the regularity of design.

***

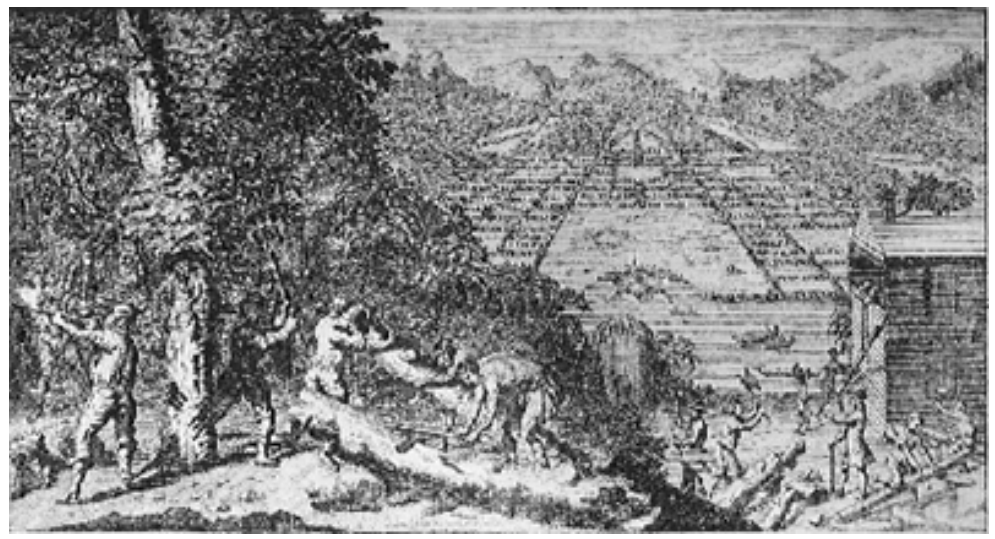

Fig. 3

\section{Imartyn.htm}

A different order of simulation generates Benjamin Martyn's etching "Reasons for Establishing the Colony of Georgia" (1733; fig. 3), an 18th-century "tourist brochure" that improvises a fantasy valley "Savannah" out of the lowland actuality; Martyn's etching is hardly a representation at all (at least not one of material realities), lacking, for most of its imagery, a referential base. It is a free elaboration of desire, barely fettered by material conditions. A compact, fortified city is shown surrounded by farms, orchards, and a distant range of mountains. The city itself is reduced to an emblem midground, and the plan, the abstract pattern of subdivided rectangles surrounding squares, is displaced to the outlying farms. As in Gordon's dry point, the point of view is elevated, from across the Savannah River above Hutchison Island; the difference is that this view is not "aerial," but "grounded" in a fictional, exotic, densely forested hill or mountain summit (rhyming the mountains in the background), atop which the settlers are too busy hunting; felling thick trunked, sensuous trees of an unusual species, and building roomy, two-story cottages, to take note of the rationalized and romanticized vista.

Too busy, but also without the need to contemplate the civilizing prospect-they are its very being. Clearing the wilderness, working alongside sparsely clad, satyr-like, though cooperative "natives" (who look more like extras from classical mythology than Native Americans), the settlers reenact the same, institutionalizing dialogue in the foreground of the image that the tutored (and tutoring) landscape--schematically laid out farms and cultivated land--symbolizes in the background. The human actors are featured here because they are signified as the manufacturers (if not the ultimate engineers) of the happy ending across the river. In Martyn's promotional/propagandistic etching, the viewer is directly addressed and given "solid" ground (an imaginary hill) to stand on; the point of the publicity packet is to lure potential colonists into the simulation, initiate imaginary narratives of days of healthy labor in an exotic and exuberant terrain that culminate in the comfort, peace of mind, rationally buttressed spirituality, and harmony--or enlightened compromise--with nature emblematized 
by the timeless city in the verdant valley; "our work is for today put our peace is everlasting" would have made good copy.

From the center of the bulwarked little city across the river rises the dark needle of a spire, exaggeratedly attenuated like a rococo pushpin fixing an ideology. It may seem ironic that Martyn depicts Savannah as an expertly fortified city--in such a state of grace, what need would there be for earthwork battlements? The image (along with the aristocratic "overseer," midground) reminds viewers that the military authority of the colonizer is what guarantees the peace and harmony, a message that reverberates throughout the landscape. In the background, vast arborescent Xings traverse ruled farmlands, verdant scarifications on the face of the landscape, "implanted" signs imaging a prohibition and a progression, inviting cultivation while warding off the "wild."

Or you might push down on the spire and set the tiny city spinning like a top over planed fields... forward a century (there are no xings, or even strong diagonals, in Gordon's cartographic vision of the same year) to...

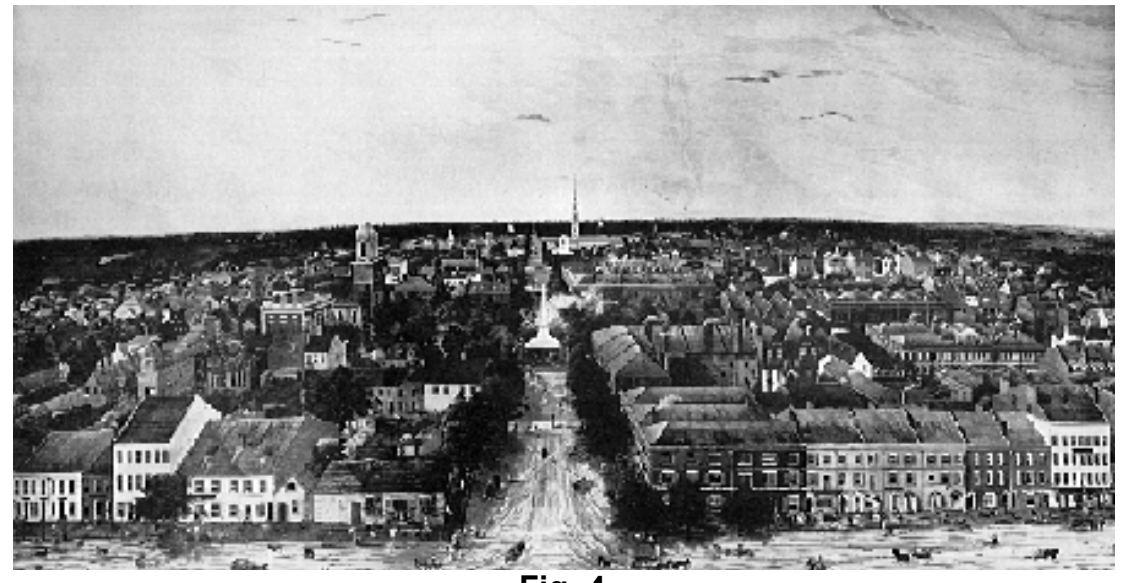

Fig. 4

Firmin Cerveau's 1837 tempera panorama/ pictographic map of Savannah (figs. $4 \& 4 a$, below). Looking down on the city from the top floor of the 19th-century Cotton Exchange (which would be just a bit to the east of Oglethorpe's tent in Gordon's 1734 map), the conceptual framework apparent in both Martyn's and Gordon's representations has been submerged beneath a profusion of surface detail, as if the 19th-century artist/cartographer (and the wellheeled viewers/buyers of these popular scenic "maps") has internalized--or become absorbed, consumed by--the "plan" and now, no longer needing (or being able) to "see" (literally, but also, to acknowledge)--its ideological underpinnings, is free to elaborate the conceptual vision into a reality-effect. Oglethorpe's rationally rhythmic vision has been reinscribed as a (well organized) display of goods. 


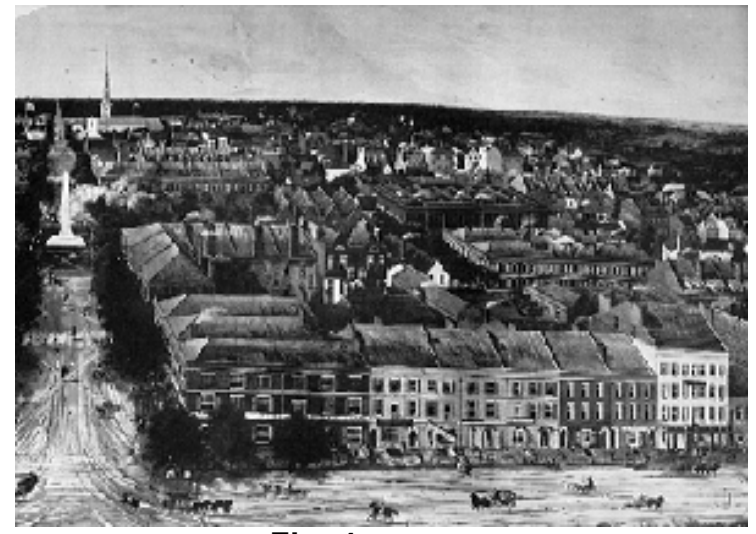

Fig. 4a

Unlike Gordon's engraving and Martyn's print, the 19th-century painting positions the viewer slightly above, though still within the gravity of the scene represented (appropriately, from the top floor of the 19th-century Cotton Exchange, which would be just a bit to the east of Oglethorpe's tent in Gordon's 1734 map). The gaze, guided by its era's episteme, does not so much contemplate the scene as become enthralled, consumed by the wealth of its era's cultural products (see also Toledano, 126)--not just the represented scene, but the signifying materiality of the painting itself. As in Gordon's "View," structures dominate over human presence, though here it is a clustering of objects, a (comparatively) dense and complicated visual surface, a multifaceted geometrization of space (contrasting also with the tropical exuberance being tamed into linearity in Martyn's engraving). In the mid 19th century, as one of the leading cotton trading centers of the south, Savannah was at the height of its economic power. The geometry of the original plan, however, barely detectable through the surface fetishization of detail, imparts a sense of stability and security--of "at homeness" with(in) the "plan"--a sense of structural integrity deeply rooted in the city's foundational schema. The strong, wide line of Bull divides the image into two large squares of equivalent weight; the white, Johnson Square obelisk centrally anchors the picture plane (not unlike the pushpin city in Martyn's vision), fronted by a faint but precise "Xing" of walkways. The voice of order and harmony that spoke clearly through Gordon's reinscription of Oglethorpe's townscape wells up uncannily here, like a return of the repressed, though the mass of surface detail.

\section{hist/omsogle}

Motivated by a vision not dissimilar to that quickening the reformist ideal of Oglethorpe's "rule" of the square, Frederick Law Olmsted counters this 19thcentury materialist malaise by arguing that squares and/or parks, incorporated into urban design, contribute to the physical and psychological well-being of the citizen, hence insuring the health and stability of the society as a whole: "We want...the greatest possible contrast with the restraining and confining conditions of the town," Olmsted asserts in 1870; "What we want to gain is tranquility and rest to the mind" (Sutton 80) (as the parallel flow of syntax emphasizes, a "tranquil" mind is not a disruptive, rebellious one). Pop histories and "historical" tour guides, published a century apart, continue to reproduce these values, keeping them in circulation. 
/tour/texts

In Historic and Picturesque Savannah (1898), Adelaide Wilson quotes a $19^{\text {th }}$-century biographer of Oglethorpe:

"'His imagination depicted a populous city with a large square for markets and other public purposes in every quarter; wide and regular streets crossing each other at right angles, and shaded by rows of noble trees. The forty rough wooden houses... would give way to durable and stately abodes; above the foliage would arise the towers and spires of numerous churches'" (9).

Like a Disney automaton, the "biographer," Robert Wright, (rear)projects a version of Oglethorpe from the 17th century into his own era, forecasting what already is--"noble" trees (fertile, but "civilized" growth) and "stately" residences (i.e., large, but not excessive, and well governed). Wright's re-visioning of Oglethorpe's vision of "Savannah," conveyed (trans-scripted) through Wilson into a turn-of-the-century American socio-economic milieu, is a narrativizing figure of order, control, class consciousness, and religious authority, at once more humanist, less disembodied and structuralist than Gordon's sublimation of mechanical draftsmanship, and more hierarchical (the implied secular openness of the squares overseen by the panopticon of church spires).

The introduction to the elaborately (over)wrought pictorial space of William Mitchell's photo-history, Classic Savannah (1991), recuperates 18thcentury ideogrammatic inscriptions of the "plan" through a psycho/genetichypostatization that eroticizes the city's "past" and makes character a function of the plan, rather than simply controlled/surveiled by it:

Classic Savannah is about living in this city where heritage and charm are civic virtues; where the power of the past is not denied but relished and proclaimed; where Georgian means British origins, styles and fashions, character, atmosphere, and affinities modified by the deep southern latitude of Savannah (3).

Orienting his gaze toward the point of view of the individual citizen, rather than the planner (as Wilson does in Historic and Picturesque Savannah), Mitchell images the past is a lover to be "relished," but the power to enthrall is contained, semantically, by streets of nomination and definition. From the author's perspective, Oglethorpe's plan, then, was not just the design of a city, but the "seed" of an entire mise en scene, enveloping landscape and the "characters" inhabiting it; a world view, an ideology, a way of seeing and being becomes an internalized map, a "natural" part of everyone born ("conceived"?) into the plan. Which is why, then, the physical and symbolic presence of the squares, key elements of a social and cultural design, are urgently important in a postmodern world of transience and mobile populations, tourism, diasporic displacement, global capitalism and information networks; the squares represent the vital presence, the currency of an old, stable order and a plan for a carefully measured, controlled, ironically ahistoric mode of development that claims that the "natives" are inherently part of the design--functions of it, morally selfmonitoring--and that everyone else is an "other." The eventual trans(re)formation of the squares into mini parks, beginning in the early 19 th century (Morrison, 8$)^{5}$, is foregrounded in contemporary urban design theory (from Olmsted's village-inthe-city concept forward) (Olmsted, 76; Toledano, 127); following suit, late 19thand 20th-century revisionist historians (such as Wilson and Mitchell) retouched 
the fundamentalist, rehabilitation-camp, proto-Enlightenment ideo-actuality with a decorous civility. In the passage quoted above, the closing prepositional phrase, "by the deep," lets us slip out, for a moment, to where we can't quite touch bottom, but "latitude" swiftly grounds us in the security of a measurable surface, which Mitchell geo-temporally reinscribes as "Georgian" become 20th-century American ideal of propriety.

"Welcome, ladies and gentlemen, and make yourselves at home in Savannah, Georgia, a tweny-first century Georgian town" (3). Now, how do we make ourselves "at home" in a "Georgian town"? Welcome to Old South Tours (/oldsouth).

Everyone entering this romanticized historyscape is easily seduced and penetrated by its ideosphere: "The best way to see Savannah is to walk through the town, inspecting the buildings carefully, looking up at the shady trees and feeling the rhythm of the town plan" (Mills Lane, Savannah Revisited: A Pictorial History, 1977, 202). In his picto-history Lane suggests that we treat the city as mise en scene to performatively (re)mythologize it: "The best day to see Savannah is on Sunday, when the twentieth century automobiles retreat to the suburbs and the old neighborhoods of Savannah regain their nineteenth century tranquility " (202). Yet this experience is to be understood as "authentic," rather than fictionalized--what Lane's walker feels "the rhythm of" is "not a museum, but a living city" (201). Lane demonstrates how current socio-economic conditions test the resilience and affective impact of Oglethrope's plan: he fears the onslaught of a "flood of tourists" (presumably a large part of his readership) who "will bring with them tawdry commercialization, creating a synthetic, carnival atmosphere" (we can read "carnival," of course, as unruly, out of control, as well as cheap and superficial, not only an assault to his vision but also a threat to the characterological-behavioral reformism that the topography (physical and psychological) of the squares stage. So far, however (i.e., up to the time of Lane's inscription), the plan has proved invulnerable as a touchstone of authenticity: "In a well-intentioned but misguided effort, public funds were expended in 1976 to pour fake concrete 'cobblestones' and 'bricks' on many streets and sidewalks of Savannah, inevitably confusing what is real with what is fake" (Lane 201).

From the standpoint of contemporary urban design theory, Oglethrope's plan is a paradigm of "urban cognition"--a sense of security deriving from qualities such as "clear identity and structure" that gave the original settlement "imageability" (or "legibility") (Altman, 32). By current urban design standards, however, the abstract, rigid beauty of Oglethorpe's vision lacked more humanizing aesthetic features, such as "naturalness," appealing "architectural style," and a sense of "spatial prospect" and "mystery" (Altman, 41). Hence the eventual trans(re)formation of the squares into mini parks, beginning in the early19th century (Morrison, 8), ${ }^{6}$ is foregrounded in contemporary urban design theory (from Olmsted's village-in-the-city concept forward) (Olmsted, 76; Toledano, 127); following suit, late 19th- and 20th-century revisionist historians (such as Wilson and Lane) retouched the fundamentalist, rehabilitation-camp, protoEnlightenment ideo-actuality with a decorous civility.

Lee Adler, founder of Historic Savannah Foundation in 1957, asserts a reformist view similar to William Mitchell's Classic Savannah sans the Eurocentric, elitist rhetoric, hence perhaps closer to the general's vision: "The plan is discipline; this basic unit of order, its architectural rhythms, repeated, 
make Savannah as we know it" (Adler, np). The persistence of the rule of the square is heard like a pulse beat through Adler's rhetoric. " It's an 18th-century plan that has endured. If you are a native--if you have family roots here--you feel part of the city; the plan is the basis of urban life here, and the square is the basic fabric of the Savannah" (Adler, np). In this view, the squares are simultaneously ontological ideograms (equations of a neo-Emersonian "oversoul") and quantum units--the DNA--of a civic identity in which city and citizens are functions of a single, overarching blueprint.

Chan Sieg's Eden on the Marsh: An Illustrated History of Savannah (1985) is a further textualization of "Savannah" as a cipher for protoEnlightenment socio-political taxonomies: "Savannah is a new city raised on an old foundation... Oglethorpe gave Savannah more than a city of streets and squares; he imbued his city with a fountain of ideals...." (147). This rhetorical staging of the historically grounded ideo-inflation of an urban design conflates "imageability" (Altman, 32) with moral value. Many of the "Ideals" Seig attributes to Oglethorpe (including proper use and distribution of land, religious tolerance, equality of opportunity--i.e, the banning of slaves in the original charter-- and moderation) palimpsest contemporary issues, reading them back through the founder's "plan"; it's unlikely that Oglethorpe would have framed his vision in quite the same way. Or, figured another way, "Oglethorpe" is like a more than lifesize mechanical Disney doll that Sieg projects his (society's) moral concerns through, or a faceless plaster semblance animated and colored with a set of beliefs and values. Take, for example, the currently popular social-political concept "equality of opportunity." This is not "equal" to the concept of banning slaves (which had a much different meaning for Oglethorpe). In colonial, prerevolutionary America, and in Oglethorpe's enterprise in particular, "equality" had a slightly different spin from the momentum it gained after the Declaration of Independence. The mathematical precision of Oglethorpe's dispensation of lands, the conditions of ownership (land in exchange for military duty), and the moral rigidity and sobriety built into the founding charter (alcohol was banned along with slaves) suggest not so much "equality of opportunity," but equalization and uniformity: development of an adequately sustained, disciplined work force to carry out the colony's business (the business of reform and, initially and briefly, silk production) (Toledano, 83). ${ }^{7}$

Perhaps partly in an attempt to deromanticize Oglethorpe's plan, the objectivist rhetoric of the 1997 National Trust Guide to Savannah strategically demystifies fantastory to create the reality-effect of "history."

Oglethorpe's other lasting contribution to Georgia remains visible today. His plan for Savannah has stood the test of time and growth from 140 persons around four squares in four wards to a city of over 150,000 that retains many of the elements that Oglethorpe and the other Trustees worked so hard to implant at Savannah (Toledano 59).

Uncannily, the concepts in Adelaide Wilson's Historic and Picturesque Savannah (see above) and Toledano's passages, written a century apart, are isomorphic, though the linguistic packaging is different. While the Guide strains to remain "factual," unaffected by its signifiers--deploying statistics and a generalizing, understated phrasing ("retains many of the elements"), underneath we hear the 
whisper of a version of a story told in 1898, itself a variation on the script of the 1734 engraving; and though what follows in the 1997 Guide is a statistic-studded history of the squares, the discourse slips, sometimes, on a single signifier-"implant" To "implant" an "element" is to organically root the inorganic; but what's being implanted is an allegory, the imagination of a teleology. As in Cerveau's "View," Oglethorpe's scheme still "remains visible" (in the Guide's view) as an underlying, directive force, foregrounding a concept of stable urban development and reinforcing (reinscribing) a representational order, while guiding the order and progression of signification in the Guide itself, including the Hegelian flow of rhetoric ("growth from... to a city of over..").

In a later passage, the rhetoric is more forceful, more blatant, pitting mathematically precise reason and moral rectitude against a rhetorically ambivalent depiction of "nature," and the "human," suggesting that the contest is between discourses--nature as representation v. city as rhetorical scheme--not representums:

From a planner's point of view, Oglethorpe's genius was the incremental potential of the plan. Wards could be laid out as needed in an urban, commercial-residential mix, so placed as to appear suburban in spatial relationships. The setting, with its squares, is tranquil and green, but the organization is tight and urban. The human-manipulated spaces contrast with the exuberance of the natural tropical growth (62).

The deconstruction of opposing categories--urban/suburban, commercial/residential--is an insightful improvisation on the "plan." Yet another, more purely rhetorical maneuver is more puzzling. The squares are "tranquil and green," but also exuberant and tropical; spaces are "human manipulated," but informed by an abstract, perhaps exponential, "incremental plan." In the Guide, "Nature," the "Human," and the "plan" are masks for a ideologically driven semiosis; mounting 20th-century notions of individual agency on 18th-century experiments in systemization, the Guide's rhetoric performs a self-inconsistently without (apparently) marking (knowing) the difference, deploying on while slipping out of phase with the "real" it codes. ${ }^{8}$

The 1997 National Trust Guide to Savannah images the manner in which 19th century object fetishism altered the semiotic valence of the squares. Oglethorpe's squares were ontological ciphers, graphic elements in a universal design, signings on (incisions in) the body/territory of the other; by the 19th century, as the ideological schema collapsed, like a dying star, into the "thing itself", producing a fascination with manipulation of the material world, the squares themselves became "objectified," rooted in material reality and the economy of consumption.

.The squares served as outdoor living rooms, crowded with shrubs and flowers, vegetation patterns that were reflected inside the houses with textiles, upholstery, drapery, tiles, and wallpapers. Hallmark of the Victorian period, when architecture began to ring these squares, was ebullience of decoration--materialism and consumerism gone wild-reflected in collections and objects from all over the world. A multitude of decorative arts inundated the Victorian aesthetic, extolled in magazines, pattern books, agricultural reviews, and texts. Profusion reigned inside the houses and outside in the squares, where the tropical climate encouraged palms and palmettos, live oak trees, and monkey grass. Moss hung from 
trees like the fringe hung from shawls over the interior grand pianos. Today that exuberance of growth is represented by clustered azaleas, crepe myrtle, and the age-old live oaks... street lamps, gazebos, and monuments and fountains were being installed as furniture for the outdoor parlors. These were replacing the original town wells, water towers, and other public facilities that characterized each square beginning in Oglethorpe's time (Toledano 126).

Oglethorpe's figures of reason became "accoutered," in practice, to realize a social ideal; by the 19th century, the squares' surfaces had begun to atomize into metonymic drifts--a play that briefly infects the surface of the language in the passage above (the movement from "moss" to "shawl," for example). The Guide salvages them, however, if not precisely for Oglethorpe's "plan," then at least for a romantic offshoot of it. By collapsing the boundaries between inside and outside, not so much to explode or deconstruct notions of private space or to invert and hence problematize the dualistic relationship between private and public, personal and social--the metonymic suggestion of "collections of objects from all over the world" could open onto a festive wilderness of hyperlinks--but in order to re-domesticate the squares, the Guide reduces and refigures them as "Hallmark" versions of Oglethorpe's more formally structured communalism: "The squares make Savannah a series of villages ${ }^{9}$ in an urban setting. The mystery is whether to call Savannah 24 small villages, or the city with the most sophisticated and livable plan in North America" (Toledano 127). These syntactically straightforward statements, and the binary, coordinate structure of the second sentence ironically dispel all "mystery" (a mystery briefly opened up by the possibility of "Moss" drifting to "shawls," for example) and shore up the stability and authority of the Guide's rhetoric and, by proxy, the Master's Plan.

\section{crit.org}

Despite its positivist stance, what the Guide perhaps can't acknowledge (symbiotic as it is to the tourist economy) is that Savannah's ubiquitously promoted "Victorianness" is a diachronic masquerade. Because Savannah did not diversify when industrial development took hold in the 1880 s, but stubbornly stuck to its ethereal agrarian past (i.e., cotton was "King"), when cotton prices began to fall, in 1895, Savannah's economy nosedived, too, and didn't pick up again till the last quarter of the $20^{\text {th }}$ century, thanks to SCAD, tourism, and bigmoney, employee-intensive companies like Gulfstream Aerospace Corp. (jet aircraft), Union Camp Corp. (paper products), Brasseler USA Mfg., Inc. (dental instruments), South States Phosphates (fertilizers), and, most recently, Hutchinson Island (a 900 acre office, hotel, retail, residential housing and recreational complex employing over 4, 000 workers) ${ }^{10}$. Consequently, downtown Savannah froze, in terms of classic architectural styles, in the 19th century (there are glaring contrasts, for example, between Victorian and "contemporary" modes, but little Art Nouveau or Art Deco development). Thus the romanticized, stereotypically feminized, mystifying image sold now, in tourist brochures, of a refined, peaceful, gracious, and splendid city ("one of the most enchanting and exquisite... cities in the world, according to Simply Savannah visitor's guide), with "architectural treasures" around every corner, its "historic" 
inns offering "the beauty and serenity of a bygone era" (Magnolia Place) and the "ambience of gentler times past" (The Mulberry) is, despite the lulling quality of its rhetoric, contentious (deployed on a highly selective set of referents) and, even more ironically, based, in part, on economic collapse. "Like a flirtatious antebellum belle, Savannah is vivacious, coy, and elusive, with hidden charms that dare to be uncovered" (Simply Savannah Visitor's Guide, 2). The coyness of the metaphor may arouse interest, but, as is the case with most self-conscious displays, the "charms" are likely to be all on the surface, and the hidden ones largely a rhetorical veil; the "belle" is really a Blanche DuBois, and while the simile titillates, it skirts historical circumstance.

It also skirts current socio-economic realities. Today, the threat of a disruptive other, once recognized in the self and scripted into the selfreconnoitering municipal design, has been displaced to others outside the self and banished to the margins of the frame (housing projects to the east and west; low-income, "unrestored" neighborhoods to the south). The social and economic boxing-in of the fashionable Historic District, which especially since the advent of Savannah College of Art and Design in the 80s, and the ensuing wide-scale preservationist and tourist marketing of the city's history, has seen a resurgence of investment capital and upscale residential/restoration interest, has made the squares a more visually potent symbol of law, order, and value than perhaps at any time in the past since the first four were laid out--like four sides of a larger ideological figure--in 1733. This perspective brings the squares more urgently into the present as consumable symbols of an unattainable sub-stance. Seen from the point of view of a tourist map, a checkerboard archipelago, Savannah may give the illusion of being above typical urban socio-economic ills, but for most people in the area, the lifestyle implied by leaded-glass doors, Italianate window moldings, and tastefully landscaped, well-tended greenery is more dream than reality: according to 1990 census figures, median household income in the 01 zip code--which includes the Historic District-- was \$12,077 per annum; in 2000 , that figure rose only slightly to $\$ 18,100$, while per capita income ranged from $\$ 13,091$ (in 1990) to $\$ 15,271$ (in 2000) and 42.5\% of households (in 2000) were making less than $\$ 15,000$ per year, with $34 \%$ of families $(39.2 \%$ of individuals) falling below poverty level (under $\$ 15,000$ per year) ("American FactFinder," ww.census.gov). Yet real estate values in the historic downtown are some of the highest in the country, Victorian town houses currently priced from $\$ 700,000-\$ 2,000,000+($ Dunn, $\mathrm{np})$. Recent crime statistics are another indicator that all is not well in Eden. Looking at per capita percentages, the crime rate in the North Historic District in 1998 (Bay to Liberty Streets, downtown proper, which includes 14 of the 22 extant squares) was $43 \%$, one of the highest in the city. This crime rate fluctuated only slightly over recent years (from a high of $49 \%$ in 1993 , to a low of $43 \%$ in 1994 , then back up to $48 \%$ in 1997 , with a slight drop in 2008 to approximately 40\%) (Savannah-Chatham Metropolitan Police Department, "Neighborhood Crime Statistics," np), and although these statistics to not distinguish between transient and resident populations (most of Savannah's tourist traffic is centered in the historic downtown), the sense, for those who live in the area, is that one is always (one out of every two) just this side of falling victim to forces that somehow evade containment and control; one has to be wary, "aware of where you are," cautions Realtor Celia Dunn, who owns a town house on Madison Square in the South Historic District (Dunn, np). 
Consequently, in the postmodern period, charged by an "internal polemic" (to borrow a phrase from Bakhtin) with their own history and present circumstances, in a gesture suggestive at once of magic realism and criticallyconscious self-commentary, the squares have become, as substantial objects of desire, more squarely present than at any time in the past (outside of the mythtime of Gordon's "View"). "Quoted" by granite curbs, their geometries are accentuated internally by neatly edged walkways and carefully manicured and maintained foliage (according to the Savannah Park and Tree Department, the annual budget for square maintenance increased $6.9 \%$ over the five year period from 1992-1997) ("Park and Tree Management Review," 8). Hence, while as green spaces they have become more lush--a landscaping equivalent of their imaginative valence--they have simultaneously become more sharply defined as squares, bringing them closer than ever to their founding ideal, as articulated in Gordon's 1734 etching. Though a paid municipal police force has displaced the technology of self-surveillance (resurfacing in the form of "neighborhood watch" organizations); though the squares look much different now than they did in the 18th century, they image a renaissance in a more essential sense, recoding the structuring values and concepts as imaged in the Oglethorpe/Gordon "original."

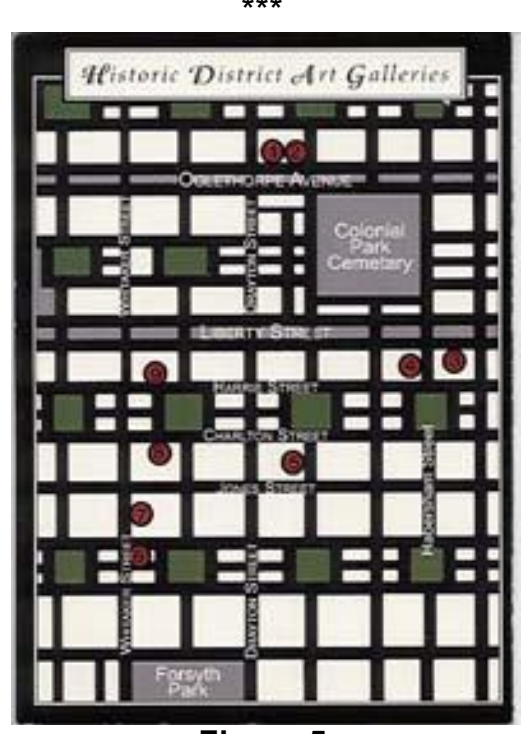

Figure 5

Imap

Contemporary scenic tourist maps also retrace, in a way, to the simplicity and abstractness of the earlier mapping visions, due in part to the economics of printing and the necessity for quick, concise dissemination of information, as well as to an aesthetic rising out of an altered cultural terrain. As noted above, in the typical tour brochure map (see fig. 5), we look directly down on the abstract image, collapsing space between viewer and representation; we no longer need the illusion of three-dimensional space, as so much of our media "enhanced" reality--the space of our productscapes--exists in two dimensions, on screens and through lenses. A late capitalist, postindustrial, high-tech, media-driven consumer economy has heated-up and altered the commodityscape, producing a different style of "good" that exists in "hard" and "soft" forms (rather than just "dry" and "perishable"); the important thing is to get consumers in the field and 
keep them there as long as possible. The basic rhythm is purchase, discard, repurchase, rather than purchase, contemplate, and save; there are always new products, or new versions of old products, to try out. Tourism thrives in the atmosphere of the soft product, mirages shimmering above the hot asphalt of the commercial pavement. In terms of the squares, the important thing is to disseminate, to sell, easily imaged (and mnemonically retrievable), highly portable simulations of the "Old South" milieu; excessive detail and particularity, historical complications or contradictions make the average tourist uncomfortable and slow down, even impede, the flow of goods, services, and information. Sell the consumer a tour, a bit of "history" to satisfy the postmodern hunger for information, but make it quick and painless; get them on the buss, then off the buss and into the shops; out of the shops into the restaurants; above all keep them moving--that's the message behind the rapid beat muzak of theme parks-since passage through the consumerscape, the "society of the spectacle," requires purchases (of objects, of images, of nourishment) to sustain it ("real" hunger and thirst are common physiological responses to immersion in a sea of simulation). So the "simplicity" of Oglethorpe's 1733 plan uncannily resurfaces in the contemporary tour map, as the "actual" tour collapses three dimensions into two; again, the map determines the territory. Purity and simplicity in concept and design, ease of movement, and the ready availability (of hard and soft products) are perhaps more urgently necessary when demographic realities threaten our desire for comfort and stability; we not only need assurance, through various media messages, that our value system is current (i.e., in circulation), but that it can be quickly snatched up in some readily demonstrable (consumable) form.

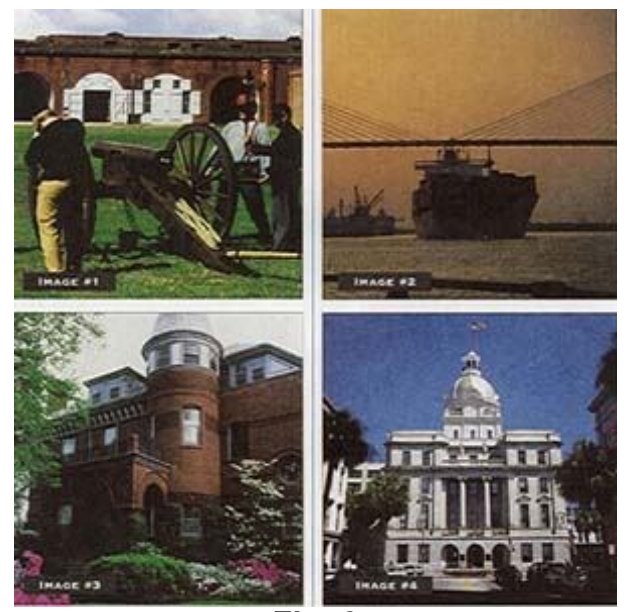

Fig. 6

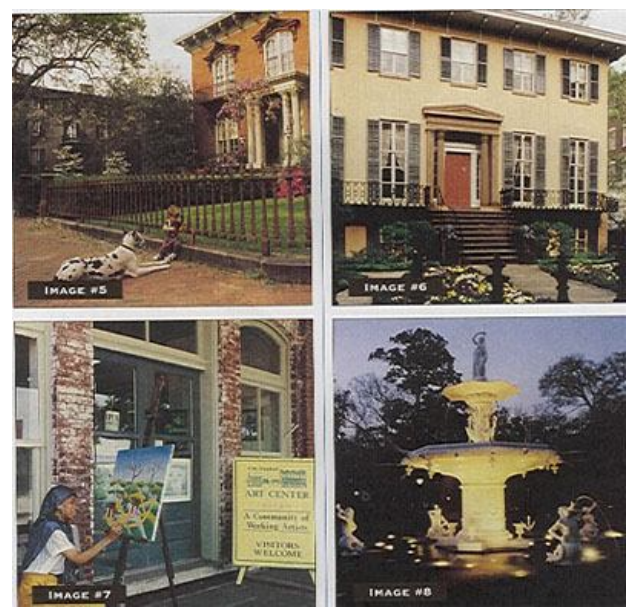

Fig. 7

\section{Ipromo.htm}

Central to the image trade at the center of a highly suburbanized city (a thirty minute ride south of downtown down Abercorn St., past a showscape of variously conceived shopping centers and chain restaurants, ends in the grand Savannah Mall) is its promotional packaging. Consider, for example, the material distributed by the Savannah Downtown Neighborhood Redevelopment Association to attract new business to the Historic District, carefully framing out such flat, non-lyrical, generic aspects of the city as the Abercorn strip. The 
packet contains a brochure, "Simply Savannah," and a booklet of the same title. The brochure features over 81 festivals and events held throughout the year, most of them downtown, free, and many outdoors, including jazz and classical music concerts, masked balls, staged reenactments of revolutionary and Civil War events; of course there are the tours: historical walking tours, the "Holiday Tour of Homes," ghost tours, "The Book" tour, and international arts, crafts, and food festivals. The booklet's opening section, "Savannah Story Ideas," offers quick-read (two-three sentence) narrative capsules as germs or suggestions, "inspirations" for individual textualizations of the city. These brief captures, or minute narratives, image Savannah as a compact historic center ("The city with the nation's largest urban historic landmark district" conveniently packed into "a 2.2 square-mile area"), a "Walking City" ("your feet are your ticket to shops"), a Garden City (whose "gem-like squares are virtual gardens"), a "Cultural and Entertainment City (with "jazz in the squares"), an "Inn City (we can "step back in time" at the "historic inns"), and a "Touring City" (offering a "wide range of options," i.e., means of transport--bicycle, carriage, trolley, bus, boat). Overall, the section emphasizes the ease of travel through the various scenarios, and the virtuality--the imaginative valence--of the experience. We can get our history with our comforts and consume the "variety of architecture" and "lush green squares" as at restaurants that "please every palate." Appropriately (and ironically), the one page section opens with "history"--i.e, appetizing "sites"/sights, a consumption of surfaces-- and closes with tourism--the more or less passive passage through the spectacle of consumption; the opening and closing blurbs are really one, collapsing the intervening pseudo categories into them(it)selves(self). The opening historical blurb is not so much a suggestion for possible narrative expansion as a statement of what "Savannah has..."; the closing blurb offers the means to turn the cityscape into (guided) fanta-story. The "Story Ideas" unfold like hypertext, presenting a prescribed (and pre-scripted) set of links; even if we decide to walk it, "guide services" are available to "personalize [our] walk." The title of the booklet, Simply Savannah, is our cue; we are positioned in a virtual relationship to the city by the text's opening section. Disingenuously, a web site is noted at the bottom of the "Story Ideas" page, which is itself embedded in a larger section, "Media services" (3). The booklet includes a "Resource List"--a brief selection of "soft" histories, pictorial works, and novels which are based on or mention Savannah--and a section describing "Savannah: In Books and on the Big Screen," which mentions TV series and movies made in, about, or with some reference to Savannah (including, of course, an "in-depth"--i.e., one full page--coverage of "The Book," Midnight in the Garden of Good \& Evil, with reproduction of the cover).

The booklet concludes with a selection of "Stock Photography" (see figs. $6,7)$ : shots of 19th-century mansions; an "artist" in the City Market outdoor mall painting a landscape in a simple, child-like style across from a sign board advertising a "community of working artists--visitor's welcome"; the old City Hall, a cargo ship passing under a suspension bridge, a Civil War reenactment, and the illuminated rococo-style fountain in Forsythe Park. These last few pages are a fitting end to the promotional booklet. Berendt's "historical fantasy" is very much like Savannah itself, a mixture of fact and fiction. The closing "Gallery" of photos emphasizes (and resizes) aspects of the city's commercial identity--its "history," public and private; its economy, based both in a trade in "real" goods and in images, and the beauty of its (architectural) surfaces. This last feature is, 
of course a qualitative presence in all the photos--even (or especially) the cargo ship is shot in silhouette against the orange glow of a setting sun. Savannah is an eminently "imageable" city because it is a city of images--in car-go.

History, in Savannah, is the business of historicizing.

\section{/hist/comspec}

The selling of a city's history does not psychologically benefit the tourist so much as the permanent residents--the belief that there is something (a "commodity") to sell, that the city's past and its values are viable and desired, is verified by the demonstrated interest of an "outsider"; ironically, the abbreviated, reductive, upbeat versions of history typically sold through a city's tour or commercial/investment packages retroactively (and recursively) reify the values and history they simulate; as the tours become more frequent and the city's image is produced, reproduced, and distributed in various formats (from mugs to movies); as the urban environment is evaluated by professional urban designers according to its "imageability," locals can complain that their "home" is being invaded and their history and cultural identity are being exploited, implying that there is a viable historical and cultural complex, something substantially there, ideologically but also as extant place, on which the tour promoters and PR agents can feed. There can be no parasites without hosts. At the same time, the abstraction of the tourist map gives the squares a contemporary, trim and rapid look--a two dimensional design of clean lines and linking quadrilateral figures, a scheme of circuitry suggesting a measured and orderly flow--a sense of hermetically sealed vehicles passing smoothly around the rounded corners of squares through a kaleidoscope of Victorian facades.

\section{.theoryl}

Where can we go from here? Turns around more squares embedded in familiar discourses of history, aesthetics, urban utopianism, socio-cultural romanticism; an ongoing tale of the same structured on the abstract surface of a rotating kiosk of ideology that has become, by default, the foundation of a world view. We come full circle, to the opening trope. Savannah is and is not a city of squares (one early 20th century director of the Department of Parks and Trees proposed rounding them off, perhaps envisioning more than he knew) (Gardner, np); it is not even mappable (as an abstract codification of external realities), but locked in a recursive circuit of reproduction of its own ever more distorted self-images-images stemming perhaps from romanticized (re)textualizations of old world aristocracy (the "old" agrarian "south")--until lost, completely, transcribed into the anonymous flow of global capital, a circus of revolving scrims flashing synonymous images in every direction, the end of metonymy... round and round we go, slightly out of phase, spiraling in total control, each turn a bit further from the last, though semiotically interchangeable with it...

\section{Select Bibliography}

Adler, Lee. Personal Interview. Cassette tape in author's possession. 14 November 1997.

Altman, Irwin, and Ervin H. Zube. Public Places and Spaces. New York: Plenum Press, 1989. 
Census of Population and Housing (1990). Washington, DC: U.S. Department of Commerce, Economics, and Statistics Administration, Bureau of the Census, 1993.

Cohen, Tom. Ideology and Inscription: Cultural Studies After Benjamin, De Man, and Bakhtin. Cambridge, UK: Cambridge University Press, 1998.

Dunn, Celia. Personal Interview. Cassette tape in possession of author. 15 January 1997.

Fox, Tom. Urban Open Space: An Investment that Pays. New York: Neighborhood Open Space Coalition, 1990.

Francis, Mark. "Control As a Dimension of Public-Space Quality." In Altman, 147-69.

Gardner, Don [Director, Savannah Park and Tree Department]. Personal Interview. 1 October 1997.

Historic Savannah. Savannah, GA: Historic Savannah Foundation, Inc., 1968.

Lane, Mills. Savannah revisited: A Pictorial History. 3rd. Ed. Savannah, GA: The Beehive Press, 1977.

Mitchell, William R. Jr. Classic Savannah [coffee table]. Photography by Van Jones Martin. Savannah: Golden Coast Publishing Company, 1987.

Morrison, Mary Lane. "On Savannah Squares." Nineteenth Century. Spring 1976: 7-12.

Nasar, Jack L. "Perception, cognition, and Evaluation of Urban Places." In Altman, 3153.

Nix, Harold L., and Charles J. Dudley. Community Social Analysis of Savannah-Chatham county, May, 1965. Athens, Georgia: Institute of Community and Area Development and Department of Sociology and Anthropology, University of Georgia, 1965.

Olmsted, Frederick Law. Civilizing American Cities. Ed. S. B. Sutton. Cambridge: MIT Press, 1971.

Rubenstein, Harvey. Pedestrian Malls, Streetscapes, and Urban Spaces. New York: John Wiley and Sons, 1992.

Savannah Park and Tree Department. "Park and Tree Management Review." Xerox facsimile of ts., 1997.

Savannah Police Department. "Neighborhood Crime Statistics." Xerox facsimile of ts., 1999.

Sieg, Edward Chan. The Squares: An Introduction to Savannah. Norfolk, VA: The Donning Company/Publishers, 1984.

Sorkin, Michael, ed. Variations on a Theme Park: The New American City and the End of Public Space. New York: Hill and Wang, 1992.

Toledano, Roulhac. The National Trust Guide to Savannah. New York: John Wiley \& Sons, Inc., 1997.

Webb, Michael. The City Square [coffee table]. London: Thames and Hudson, Ltd., 1990.

Wilson, Adelaide. Historic and Picturesque Savannah. Boston: Boston Photogravure Company, 1889.

Wittgenstein, Ludwig. Philosophical Investigations. Oxford: Basil Blackwell, 1953. vii.

Wright, Robert. A Memoir of General James Oglethorpe, One of the Earliest Reformers of Prison Discipline in England. London: Chapman and Hall, 1867.

Special thanks to Savannah Area Convention \& Visitors Bureau, the Downtown Neighborhood Redevelopment Association, University of Georgia Business Outreach Services, The Georgia Historical Society, The Savannah Historic Foundation, the Massie Heritage Interpretation Center, the Savannah-Chatham County Park and Tree Department, the Savannah Area Chamber of Commerce, and the City of SavannahChatham County Police Department for their contributions. 


\section{End Notes}

${ }^{1}$ Some of the following URLs are purely fictional, and bear no resemblance to real virtual locales.

2 See Roulhac Toledano's The National Trust Guide to Savannah (1997), Edward Chan Sieg's The Squares: An Introduction to Savannah (1984), Mills Lane's Savannah revisited (1977), and the Historic Savannah Foundation's Historic Savannah (1968) for discussions of the layout of the founding settlement.

${ }^{3}$ Attributed to Julius Caesar's engineer Vitruvius, according to historian Mary Morrison (Nineteenth Century, spring 1976). Other sources include 17th and 18th-century neighborhoods in London, such as St. James Square and Hanover Square (perhaps not unsurprisingly, Savannah's Telfair Square was originally St. James Square, codifying the landscape as a (re)cultivation based on a previous source), 15th-century Irish towns like Londonderry and Colerain, 18th-century travel maps of Peking, Robert Burnet's 1598 diagram of an army camp, and, closer to home, Sir James Montgomery's 1717 map of a proposed--though unrealized--Georgia settlement, the Margravate of Azilia (fig 1a, above). (The Massie Heritage Interpretation Center, Savannah, GA., features several of these sources in permanent exhibition.) Oglethorpe's "Savannah" is an imaginative reverberation of the latter, more exotically coded community, retaining and stressing the lengthened "A" sounds of its title, but dropping the sub-continental phonic allusions.

${ }^{4}$ According to contemporary urban designer Kevin Lynch ("Theory of Good City Form," 1981), an essential aspect of responsible city planning is to incorporate squares or square-like spaces in the urban grid, which enhance security by providing a "long view over open areas" (qtd. in Francis, 158); the disembodied gaze implied by Lynch's "view" recuperates the point of view indexed by Oglethorpe's plan (especially as situated in $A$ View Of Savannah, fig. 2): the detached, authoritarian, surveiling eye.

${ }^{5}$ According to Morrison, 1810--the year the City Council decided to enclose Johnson Square and landscape it with walkways and Mimosa trees--"marks the birth of Savannah's squares" (8); more accurately, we might say the year marks their rebirth (recreation) in a post-Enlightenment aesthetic economy.

6 According to Morrison, 1810--the year the City Council decided to enclose Johnson Square and landscape it with walkways and Mimosa trees--"marks the birth of Savannah's squares" (8); more accurately, we might say the year marks their rebirth (recreation) in a post-Enlightenment aesthetic economy.

${ }^{7}$ Concurrent with current romanticizing, theme-park appropriations of the squares is a more utilitarian concern--"The brick paths within the squares are aligned with the sidewalks of the axial streets, allowing you to walk across town, north-south and eastwest in an undeviating line" (Michael Webb, The City Square, 1990, 20)--that highlights an inherent feature of the original design-regularity, for its own sake, as facilitating the goal directed, linear motion of the grid-like flow into which the squares have been inserted. Since the squares can accommodate the consuming gaze as well as expedite the business of capitalism, overlaying Oglethrope's plan on contemporary mall design theory produces suggestive parallels: "shape, proportion, hierarchy, dominance, texture/pattern, transparency--depth by penetration of sight..." are features of effectively planned malls and cityscapes (Harvey Rubenstein, Pedestrian Malls, Streetscapes, and Urban Spaces, 1992).

${ }^{8} \mathrm{~A}$ transcendent, programmatic figuration in the Guide's next paragraph is in the spirit of Oglethorpe's plan: "Each segment of Savannah, the ward, is complete within itself but 
part of an interlocking whole. These interrelationships create tensions within the order" (62). The tension, of course, is not between a ward's per(con)ceived integrity and its function in a larger pattern; or rather, that's just where it is: between "wards" of ideological fabrication and refabrication and their relationship to/effects on our presence of mind (point of view) in transit through such experiential "sites."

${ }^{9}$ Olmsted.com. Frederick Law Olmsted's late 19th-century theories of urban design underpin the "village-in-the-city" concept package. As a counter to the potentially manic materialism near the turn of the century--as the boards of our cultural forms began to creak, the structuring framework of values threatening to collapse, the encrustation of commodities blocking all desire but the need to possess, possession an echo in the packed halls of simulation... Olmsted's voice clears a space....

Sutton, S. B., ed. Civilizing American Cities: A Selection of Frederick Law Olmsted's Writings on City Landscapes. Cambridge: MIT Press, 1971.

1870:

Opportunity and inducement to escape at frequent intervals from the confined and vitiated air of the commercial quarter, and to supply the lungs with air screened and purified by trees, and recently acted upon by sunlight... if these conditions be supplied economically, our problem would be solved.... What accommodations for recreation can we provide... strongly counteractive to the special enervating conditions of the town? (70 ${ }^{10}$ Data provided by the Savannah Area Chamber of Commerce

Tom Lavazzi is Associate Professor of English, Kingsborough Community College, New York, USA. Email: Tom.Lavazzi@kbcc.cuny.edu 